\title{
Tuition Increases Geaux Away? Evidence from Voting on Louisiana's Amendment 2
}

Joshua C. Hall

West Virginia University, jhall23@mail.wvu.edu

Serkan Karadas

Sewanee: The University of the South, skaradas@sewanee.edu

Follow this and additional works at: https://researchrepository.wvu.edu/econ_working-papers

Part of the Higher Education Commons, Political Economy Commons, and the Public Economics Commons

\section{Digital Commons Citation}

Hall, Joshua C. and Karadas, Serkan, "Tuition Increases Geaux Away? Evidence from Voting on Louisiana's Amendment 2" (2017). Economics Faculty Working Papers Series. 16.

https://researchrepository.wvu.edu/econ_working-papers/16 


\section{WestVirginiaUniversity。}

Department of Economics

Working Paper Series

\section{Tuition Increases Geaux Away? \\ Evidence from Voting on \\ Louisiana's Amendment 2}

Joshua C. Hall

Serkan Karadas

Working Paper No. 17-29

This paper can be found at the College of Business and Economics Working Paper Series homepage: 


\title{
Tuition Increases Geaux Away? Evidence from Voting on Louisiana's Amendment 2
}

\author{
Joshua C. Hall* \\ Serkan Karadas ${ }^{\dagger}$
}

\begin{abstract}
In many states, public institutions of higher education have the autonomy to raise tuition. This has not been the case in Louisiana since a 1995 constitutional amendment required a two-thirds majority of the state legislature for any tuition increase. In November of 2016, voters in Louisiana rejected Amendment 2, a constitutional amendment that would have given state institutions of higher education autonomy in setting tuition. We examine parish-level voting on Amendment 2 using an empirical political economy model and find that parishes with a greater percentage of African-Americans and university employees were more likely to vote yes. Student enrollment at public institutions seemingly did not play a role in Amendment 2 losing.
\end{abstract}

Keywords: Amendment 2, tuition increases

Note: For the international reader, "Geaux" is a French word-play on the verb go often used in Louisiana, especially in university athletics.

\footnotetext{
${ }^{*}$ Joshua C. Hall, Department of Economics, West Virginia University, Morgantown WV 26506. E-mail: joshua.hall@mail.wvu.edu

${ }^{\dagger}$ Serkan Karadas, Department of Economics, Sewanee: The University of the South, Sewanee, TN 37383. E-mail: skaradas@sewanee.edu.
} 


\section{Introduction}

The rising cost of college has been a public policy concern for at least a decade (Vedder, 2004). While there are many reasons families are paying more for college, rising enrollments and declining state aid are the primary drivers (Barr and Turner, 2013). One way that public institutions could deal with declining state support would be to raise tuition. However, institutions of higher education do not have the ability to set tuition in over two-thirds of states (Kim and Stange, 2016).

Louisiana is one of those states. Public higher education institutions in the state had the power to set their own tuition and fees before 1995, when a constitutional amendment was passed that vested the state legislature with the authority to make changes in tuition and fees. In addition, it required a two-thirds vote of the Legislature to change tuition and fees (Public Affairs Research Council of Louisiana, 2016). While the state of Louisiana did allow colleges and universities to increase tuition if they met certain performance standards related to student retention, these limited increases failed to prevent an overall budget cut in state colleges, especially in per-student appropriations. State support to higher education institutions in Louisiana declined by nearly 40 percent since the Great Recession (Louisiana Budget Project, 2016).

In response to concerns over declining state funding, the state legislature put the issue of underfunded higher education before the voters. Universities wanted the authority to increase tuition in line with the cost of education, charging students higher tuition in high demand areas and fields that cost more to staff such as business and engineering. Amendment 2 was placed on the ballot for a vote on November 8, 2016. The amendment, upon passage, would have given public colleges and universities the authority to raise tuition without approval from the state legislature.

Amendment 2 had plenty of supporters who felt that the current constitutional restraints on tuition increases were too restrictive. Jim Henderson, the president of Northwestern State University (NSU), made the case in favor of greater authority over tuition increases by 
public universities in stating that "the constitutional Amendment 2 powers the universities to respond more effectively to the needs of their markets, the needs of students (Guidry and D'Aquin, 2016)."

Despite the support among many prominent organizations and the funding issues associated with the status quo, Amendment 2 failed to pass. According to Louisiana Secretary of State (2016), over 57 percent of voters opposed the amendment. Only one of Louisiana's parishes (counties) voted in favor of the amendment - Lincoln Parish, the home of Louisiana Tech University and Grambling State University. Even East Baton Rouge Parish, the home of LSU, voted against Amendment 2 (52 percent no) (Louisiana Secretary of State, 2016).

The rejection of Amendment 2 did not bode well for colleges, especially because a $\$ 315$ million state budget deficit implies further cuts to the higher education system (O'Donoghue, 2016). News articles following the amendment's defeat highlight several reasons why the amendment might have failed despite the seemingly widespread support and need for change. NSU President Jim Henderson, for example, argued that the public may have equated tuition increases with tax increases (Guidry, 2016). Other arguments given include the tendency of many voters to automatically vote against any constitutional amendments (Guidry, 2016).

In this empirical note we try to explain parish-level voting on Amendment 2 using an empirical median voter model. We do so in order to better understand collective concerns regarding college tuition and the value of public higher education. Even as individuals seem willing to pay ever higher tuition for themselves or their children, taxpayers seem unwilling to devote more public resources to higher education in the face of other competing state demands (Barr and Turner, 2013). Our results show a positive and statistically significant relationship between parishes with higher rates of college educated citizens and the percentage of yes votes on Amendment 2. This finding disappears, however, once we control for the percentage of parish citizens that are university employees. We find a strong and positive relationship between the percentage of a parish that is African-American and yes vote percentage. We find no consistent negative relationships. We discuss the implications of our 
findings in our conclusion.

\section{Data and Empirical Approach}

In employing a median voter model to look at constitutional change, we are following the seminal work of Crain and Tollison (1979), who look at constitutional change from an interestgroup perspective. We use median voter model as shorthand for a model that has variables that capture features of the median voter - such as median income - as well as applicable special interests (Congleton and Bennett, 1995). Recent empirical papers using similar models to explain constitutional or policy changes include Kimenyi and Shughart (2010), Hall and Shultz (2016), and Neto et al. (2016). Following the literature, we try to explain parish-level votes on Amendment 2 using median voter and interest group variables at the parish level.

Our dependent variable is parish-level percentage of yes votes from the Louisiana Secretary of State (2016). Our explanatory demographic and economic variables come from the United States Census Bureau (2016), which provides 5-year estimates over the 2010-2014 period. We use the following variables to capture median voter and interest group preferences: median household income in $\$ 1000$ s, percentage of government workers, percentage of population with bachelor's degree or higher, percentage of civilian veterans, and percentage of African-Americans. We also included variables representing university or community interests such as the number of universities in the parish, resident students enrolled at public institutions of higher education as a percentage of parish population, and university employment as a percentage of parish population (calculated from Louisiana Board of Regents $(2017))$.

Our reasoning in including these variables is relatively straightforward, with the exception of veterans and African-Americans. Our hypothesis is that veterans are more in favor of the centralization of authority in the legislature and less concerned about tuition increases given 
either advanced age or access to military-related education funding. African-Americans, on the other hand, tend to have below average incomes and thus might be concerned about tuition increases. Prior to Amendment 2, some expressed concern about tuition increases having undue burden on low-income students (Louisiana Budget Project, 2016). On the other hand, Kim and Stange (2016) find that university autonomy in pricing in Texas led to an increase in institutional grant aid that offset tuition increases for disadvantaged students.

Our variables representing university presence and employment should be positively related to the yes vote. In addition to reflecting the self-interest of university employees, these variables should capture the extent to which universities are important in the local economy. Resident Student \% is hypothesized to be negatively related to yes percentage as students might anticipate paying higher tuition should Amendment 2 pass.

We estimate our model using Ordinary Least Squares (OLS) with robust standard errors and present our results in Table 1. The column labeled "Sample" contains the mean and standard deviation of our variables. Our model explains between 59 and 65 percent of the variation across parishes in voting, depending upon the specification. We find consistent statistically significant evidence that areas with a higher African-American percentage were more likely to vote yes on Amendment 2. This is the case no matter the specification.

We find two demographic results that disappear once university interests are included. Veterans of the military and those with a college degree or higher were statistically significant until university employment was included. The insignificance of College Degree or Higher $\%$ in Column 4 should not be surprising given the high degree of correlation (over 50\%) between college attainment and university employment. While we found the percentage of college students in a parish to never be statistically related to the yes vote (even in a simple regression including only this variable and a constant), university employment was always positively related in a statistically significant way to yes vote percentage on Amendment 2. Other explanatory variables, such as the percentage of government workers and median household income are never statistically significant, and their inclusion or exclusion does not 
Table 1: Determinants of Parish-Level Voting on Constitutional Amendment 2: OLS Results

\begin{tabular}{|c|c|c|c|c|c|}
\hline & Sample & $(1)$ & $(2)$ & $(3)$ & $(4)$ \\
\hline College Degree or Higher (\%) & $\begin{array}{l}15.791 \\
(6.388)\end{array}$ & $\begin{array}{c}0.295^{* *} \\
(0.068)\end{array}$ & $\begin{array}{c}0.279^{* *} \\
(0.090)\end{array}$ & $\begin{array}{c}0.278^{* *} \\
(0.095)\end{array}$ & $\begin{array}{c}0.123 \\
(0.104)\end{array}$ \\
\hline Veterans (\%) & $\begin{array}{c}8.716 \\
(2.253)\end{array}$ & $\begin{array}{c}-0.615^{* *} \\
(0.132)\end{array}$ & $\begin{array}{c}-0.611^{* *} \\
(0.136)\end{array}$ & $\begin{array}{c}-0.576^{* *} \\
(0.200)\end{array}$ & $\begin{array}{l}-0.344 \\
(0.226)\end{array}$ \\
\hline African-American (\%) & $\begin{array}{c}31.856 \\
(14.465)\end{array}$ & $\begin{array}{c}0.165^{* *} \\
(0.027)\end{array}$ & $\begin{array}{c}0.172^{* *} \\
(0.034)\end{array}$ & $\begin{array}{c}0.175^{* *} \\
(0.041)\end{array}$ & $\begin{array}{c}0.186^{* *} \\
(0.041)\end{array}$ \\
\hline Median Household Income (1000\$) & $\begin{array}{l}41.857 \\
(9.652)\end{array}$ & & $\begin{array}{c}0.023 \\
(0.055)\end{array}$ & $\begin{array}{c}0.021 \\
(0.051)\end{array}$ & $\begin{array}{c}0.068 \\
(0.045)\end{array}$ \\
\hline Government Workers (\%) & $\begin{array}{l}18.244 \\
(4.757)\end{array}$ & & & $\begin{array}{l}-0.033 \\
(0.113)\end{array}$ & $\begin{array}{l}-0.176 \\
(0.117)\end{array}$ \\
\hline Resident Student (\%) & $\begin{array}{c}3.646 \\
(0.914)\end{array}$ & & & & $\begin{array}{l}-0.270 \\
(0.620)\end{array}$ \\
\hline Number of Universities & $\begin{array}{c}1.094 \\
(1.080)\end{array}$ & & & & $\begin{array}{l}-0.629 \\
(0.687)\end{array}$ \\
\hline University Employees (\%) & $\begin{array}{c}0.206 \\
(0.336)\end{array}$ & & & & $\begin{array}{c}6.178^{* *} \\
(1.545)\end{array}$ \\
\hline Constant & & $\begin{array}{c}45.427^{* *} \\
(2.03)\end{array}$ & $\begin{array}{c}35.411^{* *} \\
(3.167)\end{array}$ & $\begin{array}{c}35.77^{* *} \\
(2.67)\end{array}$ & $\begin{array}{c}36.898^{* *} \\
(3.560)\end{array}$ \\
\hline $\mathrm{R}$-squared & & 0.596 & 0.591 & 0.591 & 0.655 \\
\hline
\end{tabular}

Notes: Dependent Variable is percentage 'yes' vote on Amendment 2 by Parish. $\mathrm{N}=64$.

The mean of the dependent variable is 40.99 and the standard deviation is 4.72 .

Variable means with standard deviations in parentheses in column 1.

Robust standard errors in parentheses in numbered columns.

*: Significant at 5\%;*: Significant at $1 \%$. 
change our results.

\section{Concluding Thoughts}

Our findings highlight two groups whose presence was associated with higher vote percentage in favor of Amendment 2 - African-Americans and university employees. A glib answer why Amendment 2 failed would be to say that there were not enough voters in those groups. A point consistent with public choice would be that if a policy change has benefits greater than costs, it should be possible to structure benefits and costs such that the policy can pass (Buchanan and Tullock, 1962). It would seem, based on our results, that African-Americans and university employees thought the benefits of tuition autonomy were greater than the costs but few other voters felt the same way. To pass, any future attempt at providing tuition autonomy for institutions of higher education in Louisiana will have to structure the constitutional amendment such that benefits or costs are more widely distributed in the minds of voters. 


\section{References}

Barr, A. and Turner, S. E. (2013). Expanding enrollments and contracting state budgets: The effect of the great recession on higher education. Annals of the American Academy of Political and Social Science, 650(1):168-193.

Buchanan, J. M. and Tullock, G. (1962). The calculus of consent. University of Michigan Press, Ann Arbor.

Congleton, R. D. and Bennett, R. W. (1995). On the political economy of state highway expenditures: Some evidence of the relative performance of alternative public choice models. Public Choice, 84(1-2):1-24.

Crain, W. M. and Tollison, R. D. (1979). Constitutional change in an interest-group perspective. Journal of Legal Studies, 8(1):165-175.

Guidry, L. (2016). Constitutional Amendment 2 failed. Now what? The Daily Advertiser, November 10.

Guidry, L. and D'Aquin, D. (2016). Louisiana university leaders discuss constitutional Amendment 2. The Daily Advertiser, November 1.

Hall, J. C. and Shultz, C. (2016). Determinants of voting behaviour on the Keystone XL pipeline. Applied Economics Letters, 23(7):498-500.

Kim, J. and Stange, K. (2016). Pricing and university autonomy: Tuition deregulation in Texas. RSF: The Russell Sage Foundation Journal of the Social Sciences, 2(1):112-146.

Kimenyi, M. S. and Shughart, W. F. (2010). The political economy of constitutional choice: A study of the 2005 Kenyan constitutional referendum. Constitutional Political Economy, $21(1): 1-27$.

Louisiana Board of Regents (2017). Higher Education State Fact Book: 2016-2017. Louisiana Board of Regents, Baton Rouge. 
Louisiana Budget Project (2016). Amendment 2 is the wrong solution to college funding crisis. LBP Blog, October 25.

Louisiana Secretary of State (2016). Official results. https://voterportal.sos.la.gov, December 19.

Neto, A. B. F., Hodges, C. D., and Pyun, H. (2016). Voting dynamics and the birth of state-owned casinos in Kansas. Economics Bulletin, 36(1):329-336.

O’Donoghue, J. (2016). Louisiana budget deficit: Higher education, Medicaid providers likely to be affected. The Times-Picayune, November 17.

Public Affairs Research Council of Louisiana (2016). PAR Guide to the 2016 Constitutional Amendments. Public Affairs Research Council of Louisiana, Baton Rouge.

United States Census Bureau (2016). American community survey. www.census.gov/acs/www/data/data-tables-and-tools/, December 19.

Vedder, R. K. (2004). Going broke by degree: Why college costs too much. American Enterprise Institute. 